Katarzyna Zarzycka

ORCID: https://orcid.org/0000-0003-2708-2360

Absolwentka Instytutu Etnologii i Antropologii Kulturowej

Uniwersytetu Warszawskiego

\title{
Jak mieszka „słoik”? Proces zadomawiania się w Warszawie na przykładzie studentów pochodzących spoza stolicy
}

\section{How does a "jar" live? The process of settling in Warsaw on the example of students originating from outside the capital}

\begin{abstract}
Based on studies conducted between the year 2013 and 2016, the article describes a process of settling within a place and its practical aspects among students of Warsaw public universities who come from outside of the capital city (commonly known as stoiki - "jars"). In this paper, the process of settling is understood as a relation with the city, shaped and transformed by the practices of everyday life. It describes students' motives for migration, responses to a new situation of living in a new city, changes regarding the knowledge of topography, renting a flat, travelling and movement, social relations, and anchoring of everyday memories in the space of the city.
\end{abstract}

Keywords: dwelling, migration, everyday life, migration, space, city

Autorka artykułu opisuje proces zadomawiania się i jego praktyczny wymiar na podstawie badań przeprowadzonych w latach 2013-2016 wśród pochodzących spoza stolicy studentów warszawskich uczelni publicznych (potocznie nazywanych „słoikami”). Zadomawianie się rozumiane jest jako relacja z miastem, która kształtuje się i zmienia poprzez codzienne praktyki. Omówione zostają motywy migracji, reakcja na zmianę, przemiany dotyczące znajomości topografii, poruszania się (przemieszczania się), wynajmu mieszkania, relacji społecznych oraz zakotwiczenia wspomnień w miejskiej przestrzeni.

Słowa kluczowe: zadomawianie się, „słoik”, migracja, codzienność, przestrzeń, miasto

Odebrano / Received: 31.01.2019

Zaakceptowano / Accepted: 27.08.2019 


\section{Wstęp: kim jest „słoik”?}

Niniejszy artykuł ma na celu omówienie prowadzonych przeze mnie badań zamieszkiwania na przykładzie studentów warszawskich uczelni pochodzących spoza stolicy ${ }^{1}$. Liczba przyjezdnych - łącząc tych, którzy przyjechali 25 lat temu, jak i tych, którzy wybrali się tu 5 lat temu - sprawia, że dzisiejsza Warszawa w dużej mierze stworzona została i przetwarzana jest przez migrację $e^{2}$ Należący do tej grupy rozmówcy (tzw. „słoiki”) stanowią zatem ciekawy przykład przemian zachodzących w stolicy.

Status przyjezdnych jest jednak ambiwalentny. Choć bowiem połowa mieszkańców Warszawy pochodzi spoza niej ${ }^{3}$, to istnieje pewna grupa, która uważa się za „rodowitych” lub też „prawdziwych” warszawiaków, z niechęcią przyjmująca fakt dużej migracji do wiadomości. Napięcia wytwarzające się w związku z tym doprowadziły do powstania publicznej debaty na temat warszawskich migrantów wewnętrznych. Poniżej chciałabym opisać dwie takie dyskusje (z 20044 i 2013 roku), które opisują dość długie trwanie tego tematu oraz zobrazują stereotyp słoika i przedstawią genezę tego określenia.

W dyskusji z 2004 roku używano jeszcze określenia „przyjezdny”, a w 2013 roku modny stał się już epitet „słoik”. Te dwa terminy są ze sobą związane - wydaje się, że późniejsze jest rozwinięciem wcześniejszego, używanego w stolicy znacznie dłużej.

Pierwszą z dyskusji rozpoczęło wydanie raportu „Jacy warszawiacy - jaka Warszawa” oraz publikacji „Społeczna mapa Warszawy”. Raport ukazał się w trzech kolejnych numerach Gazety Wyborczej (15-17.09.2004) i zawierał różne opinie rdzennych warszawiaków właśnie o przyjezdnych.Jedna z wypowiedzi brzmiała tak (pisownia oryginalna):

Niestety, dużo ludzi, którzy napłynęli w ostatnich latach do Warszawy za pracą Warszawy nie lubi i się z nią nie identyfikuje. Wręcz przeciwnie, zamykają się na nią, krytykują,

1 W artykule w skróconej formie przedstawiono tezy i opisano materiał zawarty w mojej pracy magisterskiej pt. Oswajanie Warszawy. Proces zamieszkiwania miasta na przyktadzie studentów spoza stolicy.

Spośród trzynastu osób, z którymi udało mi się przeprowadzić wywiad i/lub pójść na spacer, najmłodsza w chwili wywiadu mieszkała w Warszawie niecałe dwa lata i niedawno rozpoczęła studia. Najstarszy z moich rozmówców mieszkał w stolicy dziesięć lat i po skończonych studiach rozpoczął pracę. Najmniejsza miejscowość, z której pochodził jeden z moich rozmówców liczy ok. 350 mieszkańców, największa ok. 350 tysięcy mieszkańców. Były to osoby z siedmiu różnych województw, o różnym zapleczu ekonomiczno-społecznym, zainteresowaniach czy aspiracjach życiowych. Łączyło je to, że przyjechały do Warszawy na studia i nie mieszkały w stolicy dłużej niż 10 lat. Ponieważ temat „słoików” wydaje się stosunkowo mało rozpoznany, zależało mi na osobach, które, mimo rozmycia się tej kategorii, z pewnością podpadają pod określenie „słoik” i takich, które będą pamiętały swój przyjazd.

$2 \mathrm{Na}$ temat współczesnej migracji do stolicy w poszukiwaniu pracy zob. Łukasiuk 2007. W swojej pracy ograniczam się do badania zamieszkiwania przestrzeni miasta, pomijając wątek mieszkalnictwa. Na ten temat zob. Skowrońska 2015 i Woroniecka (red.) 2007.

3 Chełmiński 2017. Według Magdaleny Łukasiuk odsetek ten jest prawdopodobnie jeszcze większy (Łukasiuk 2007, s. 139).

4 Kwaśniewski 2004.

5 Grzelak, Zarycki (red.) 2014. 
między swoimi nazywają 'Warszawką', nie chcą uczestniczyć w jej codziennym życiu. Wyłącznie konsumują to miasto, a nie tworzą. Odpływają na weekendy do siebie, bo w Warszawie u siebie poczuć się nie chcą (W-WIANKA).

Powyższy cytat (a także inne wypowiedzi z tego samego źródła) przedstawia przyjezdnych jako zamkniętych na Warszawę, niechcących jej poznać, nieszanujących jej i mających negatywny do niej stosunek, chętnie powracających do miejsc, które uważają za bardziej swoje (rodzinne miejscowości).

Podczas dyskusji z 2013 roku pojawiło się już określenie „słoik”, odnoszące się do przyjezdnego i wywodzące się od szklanych pojemników z domowym jedzeniem, które przywożone są przez migrantów z rodzinnych miejscowości przy okazji powrotu do stolicy. Słoiki mają tu być symbolem emocjonalnego lub materialnego uzależnienia przyjezdnych od domów rodzinnych i być dowodem ich niechęci lub nieporadności w adaptacji.

Dyskusja o „słoikach” wypełniła wtedy przestrzenie internetu w związku z konkursem na neon dla Warszawy, zorganizowanym przez RWE Polska SA (obecnie innogy Polska SA) oraz Muzeum Neonów, który pierwotnie wygrał projekt neonu w kształcie trzech słoików ustawionych jeden za drugim. W krótkim czasie na blogach i w gazetach pojawiły się wpisy, a na Facebooku rozpoczęto akcje przeciwko jego realizacji, gdzie w specjalnie w tym celu stworzonych grupach wypowiadano się także przeciwko samym przyjezdnym $^{6}$. Muzeum Karykatury w Warszawie zorganizowało w 2013 roku konkurs „Warszawa i Warszawka, czyli dobrze i lepiej o naszej stolicy”, na który została nadesłana między innymi praca Patryka Sroczyńskiego pt. Warszawskie stoiki przedstawiająca korek drogowy utworzony z samochodów i słoików na kołach. W podobnym okresie zespół Big Cyc wydał piosenkę pt. Stoiki (tekst Krzysztof Skiba), której słowa brzmią następująco:

\footnotetext{
„Najechali na Warszawę niczym horda Czyngis Chana

$\mathrm{Na}$ furmankach, w dobrych autach ciągną od samego rana,

Zakręcone w szklanych słojach mają całe swoje życie:

Bigos, grzyby, kompot z jabłek -

I tak podbić chcą stolicę, stolicę, stolicę."
}

\footnotetext{
6 Por. „Sprzeciw wobec realizacji zwycięskiego projektu -NEON DLA WARSZAWY”.

7 Same „słoiki” nie pozostały bierne. Nie ma tu jednak miejsca, by dokładnie omówić ten temat. Osoby, które czuły, że negatywne opinie skierowane są do nich nie tylko pisały w prasie, podkreślając w swoich tekstach zalety migrantów z innych części Polski, ale także zakładały inicjatywny biznesowe, których celem była sprzedaż produktów wyśmiewających podział na „miejscowych” i „słoiki”. W 2015 roku wydana została także powieść Magdaleny Żelazowskiej pt. Zachłanni, której bohaterami są osoby, które przyjechały do stolicy. Okładkę książki zdobi Pałac Kultury i Nauki umieszczony w słoiku, co sugeruje tematykę książki.
} 
$\mathrm{Z}$ analizy materiałów, które pojawiły przy okazji dwóch wspomnianych dyskusji wynika, że choć początkowo figura „słoika” odnosiła się przede wszystkim do częstych wyjazdów do domu i uzależnienia od wsparcia rodzinnego, to jednak z czasem zaczęło ono dotyczyć każdej przyjezdnej osoby, której chciano przypisać określone negatywne cechy. Od przyjezdnego/"słoika" wymaga się zatem przeniesienia ośrodka interesów życiowych do stolicy w pełni i odcięcia się emocjonalnego oraz ekonomicznego od rodzinnej miejscowości, co wyrażać miałoby się np. płaceniem podatków w Warszawie. Nieporadność czy niechęć piętnowane przez „rdzennych” warszawiaków obrazują nie tyle wyjazdy przyjezdnych do domów rodzinnych, ile ich częstotliwość (stereotypowo „słoik” wyjeżdża w zasadzie w każdy weekend, a już na pewno przy okazji różnego rodzaju świąt, co stali mieszkańcy Warszawy obserwują jako „opustoszenie” miasta) i przywożenie jedzenia lub innego rodzaju dóbr, które teoretycznie można nabyć bez problemu w Warszawie. Sugeruje to brak skłonności migrantów do asymilacji, co dodatkowo wzbudza kontrowersje. Przywiązanie emocjonalne do dań serwowanych w domu rodzinnym czy właśnie płacenie podatków w rodzinnej miejscowości wydaje się w związku z tym dziecinne i świadczy na niekorzyść „słoika”. Osoby, które uważają się za prawdziwych mieszkańców Warszawy oczekują od „słoików” także jakiejś formy afirmacji stolicy, czyli dostrzegania jej plusów i powstrzymania się od (zbędnej ich zdaniem) krytyki. Domniemywa się, że skoro podjęto decyzję o przeniesieniu się do tego miasta, to należy być wdzięcznym za możliwości, jakie daje i spłacić pewien dług, zaciągnięty na rzecz rozwoju osobistego dostępnego dzięki migracji (zakłada się tutaj, że nie byłby on możliwy w rodzinnym mieście migranta). Jednocześnie duży wpływ, jaki mają na życie stolicy przyjezdni, rodzi frustrację i sprzeciw tych, którzy uważają, że posiadają prawo do miasta ze względu na swoje urodzenie, pochodzenie lub długie przebywanie w stolicy.

Zatem, choć jako grupa „słoiki” stanowią o tym, czym jest stolica, to jednocześnie postrzegani są jako element obcy, czasowy. $Z$ tego powodu badanie, w jaki sposób osoby te zamieszkują Warszawę, wydaje się szczególnie ciekawe. W przypadku migrantów rzadko bowiem mówi się o zamieszkiwaniu, kojarzonym zazwyczaj z kształtowaniem się tożsamości jednostki na poziomie elementarnym (kim jestem i skąd pochodzę?). Często jest ono badane retrospektywnie jako fakt, który już się dokonał i którego skutkiem jest poczucie przywiązania lub zadomowienia. Omówione zostają zatem procesy, które można by nazwać przejściem od pozycji outsidera do insidera, przy czym należy te dwa

8 Od tej pory zamiennie używam określenia „słoik” i „przyjezdny”. Nie tylko ze względów językowych, ale także ze względu na zamazywanie się różnic pomiędzy tymi etykietami. Jest to widoczne na przykładzie opisu wydarzenia "Sprzeciw wobec realizacji zwycięskiego projektu - NEON DLA WARSZAWY”: „Sprzeciwiamy się realizacji zwycięskiego projektu pt. „Warszawskie Słoiki” w konkursie Neon Dla Warszawy organizowanego przez Neon Muzeum we współpracy z RWE. (...) Podkreśla bodaj najmłodszy podział jaki występuje w społeczności naszego miasta, dzieli nas na tych „prawdziwych” i tych „przyjezdnych" - Słoiki.” 
pojęcia rozumieć jako spektrum9. Śledząc historie i poczynania moich rozmówców, rozpatrywałam, jak w toku życia w Warszawie tworzą się i przetwarzają sieci społeczne, znajomość topografii, umiejętności poruszania się, opinie i wiedza potoczna dotycząca np. rynku mieszkaniowego, a także jak wpływa to na subiektywną ocenę ich własnej sytuacji.

W niniejszym artykule zamieszkiwanie postrzegane jest w związku z tym jako czynność będąca w toku, bez oczywistego zakończenia - wyjazdu, powrotu do rodzinnej miejscowości czy pozostaniu na całe życie w stolicy. Pozwala to badać zamieszkiwanie w szerszym kontekście, wychodząc poza dychotomię mobilności i osiadłości ${ }^{10}$, zgodnie z postulatem jej normalizacji, który zadaje pytanie o to ,jak wypracować teorię społeczną, w której mobilność jest znormalizowana i postrzegana jako integralna część osadzonych przestrzennie relacji społecznych, a nie w opozycji do nich"11, a zatem nie podkreśla wyłącznie wątków pozytywnych (takich jak ruch młodej, kosmopolitycznej inteligencji) czy negatywnych (rozumianych jako ruch związany z pracą czy uchodźstwem) ${ }^{12}$.

\section{Zamieszkiwanie}

Podstawowym wykorzystywanym przeze mnie terminem jest „zamieszkiwane”, które najprościej określić można jako nieustannie wytwarzającą się relację ze środowiskiem (przestrzenią) - proces, w którym kluczowe elementy stanowią praktyki osadzone w codzienności. Tak rozumiane zamieszkiwanie ma swoje źródło w pismach Heideggera, który zauważa, że jest ono sposobem, w jaki człowiek jest na ziemi ${ }^{13}$. W ten sposób, za pomocą określonych praktyk, człowiek staje się częścią środowiska, a środowisko staje się jego częścią ${ }^{14}$, choć jak zauważa Tim Ingold, krytykując w swojej późniejszej twórczości taką perspektywę - organizm i środowisko, którego jest częścią, to elementy de facto nierozłączne: byt pozostaje zanurzony w bieg życia świata, bez czego niemożliwe byłyby takie czynności jak projektowanie, budowanie i mieszkanie ${ }^{15}$. By rozwinąc tę myśl, antropolog stosuje pojęcie meshwork, które opisuje właściwości środowiska, podkreślając, że organizmy są jego integralną częścią, a ich wyłączenie to abstrakcyjna

\footnotetext{
${ }^{9}$ Jak wskazuje David Seamon intensywność więzi z miejscem zależy od kilku czynników, m.in. położenia danego miejsca, także w odniesieniu do innych miejsc znanych danej osobie, oraz sposobów, w jaki insider/outsider rozumie, czuje czy doświadcza tych miejsc jako zamkniętych (inward) bądź otwartych (outward) (Seamon 2014, s. 16).

${ }^{10}$ Por. Gustafson 2001, s. 668.

${ }^{11}$ Glick Schiller, Salazar 2013, s. 189. Tłumaczenie własne.

${ }^{12}$ Faist 2013, s. 1642.

${ }^{13}$ Heidegger 2007, s. 141.

${ }^{14}$ Ingold 1993.

15 Ingold 2011, s. 10. Zdaniem Ingolda istniejący w antropologii rozdział na środowisko/świat i człowieka (oraz pozostałe żywe i nieżywe byty) to zabieg sztuczny, niemający uzasadnienia i przesłaniający faktyczną jedność wszystkich tych elementów (Ingold 2000, s. 185).
} 
operacja myślowa, nie mająca miejsca w rzeczywistości. Meshwork to przestrzenne splątanie przepływów substancji materialnych, krzyżowanie się ruchów, takich jak wzrost czy przemieszczanie się, wzdłuż których organizm postrzega i działa. Poprzez zdolność do reakcji (ruch) organizm może być sprawczy i nabywać oraz rozwijać swoje umiejętności w toku codziennego życia ${ }^{16}$. Zdolność percepcji i ruchu, wyłaniające się w procesie rozwoju osobniczego powodują, że organizm należy postrzegać jako działanie, co określa go jako element meshworku ${ }^{17}$. W ten sposób Ingold wiąże zamieszkiwanie z ruchem i nabywaniem praktyki w określonej przestrzeni, relacyjnością, a także rytmem codzienności. Odnosząc tę koncepcję do moich badań, należy zauważyć, że moi rozmówcy posiadają wszelkie umiejętności poznawcze konieczne do zaadaptowania się w nowym miejscu, ale by móc w pełni wykorzystać dostępne zasoby i swobodnie realizować swoje potrzeby niezbędne jest praktyczne wchodzenie $w$ relacje $z$ miastem. Podejmowane w związku z tym interakcje, w mniejszym lub większym stopniu, wpływają zarówno na nich samych, jak i na środowisko, którego częścią się stają, zazwyczaj powodując zmiany w obrębie innych elementów ${ }^{18}$ (np. rynku pracy, opinii społecznej i stylu życia).

Jak badać zamieszkiwanie? Biorąc pod uwagę kwestię codzienności oraz jej efemeryczność i związaną z tym trudność rejestracji19, sam wywiad wydawał się (i okazał) niewystarczający. Choć przeprowadzałam indywidualne wywiady z moimi rozmówcami i poruszałam w nich kwestie przestrzeni miejskiej oraz procesów adaptacji, nie odpowiadały one na pytanie o to, co stanowi o zamieszkiwaniu, jak przebiega zamieszkiwanie $\mathrm{w}$ nowej przestrzeni miejskiej, ani w jaki sposób wytwarza się związane z nim poczucie miejsca (sense of place $)^{20}$, czyli o sposoby świadomego lub nieświadomego doświadczania, użytkowania (wykorzystywania) oraz rozumienia (pojmowania) danego miejsca ${ }^{21}$, co wiąże się (ale nie jednoznacznie) z jego tożsamością, przywiązaniem do niego lub poczuciem zależności od niego, a także z przyjęciem przez człowieka roli insidera/outsidera.

Dotarcie do tego typu wiedzy możliwe staje się dzięki spacerom. Jako metoda etnograficzna jest on bardziej towarzyską interakcją niż wywiad twarzą w twarz ${ }^{22}$ i daje dostęp do tego, jak „osobiste i społeczne opowieści kształtują doświadczenie jednostek w znajomej przestrzeni publicznej”, w której „nazwy i miejsca nie mają pojedynczego znaczenia lub historii, ale raczej wiele znaczeń i historii, które "przemierzają

\footnotetext{
${ }^{16}$ Ingold 2011, s. 63-65.

${ }^{17}$ Ingold 2011, s. 117.

${ }^{18}$ Convery, Corsane, Davis 2012, s. 4.

${ }^{19}$ Highmore 2002, s. 23.

${ }^{20}$ Convery, Corsane, Davis 2012, s. 2.

${ }^{21}$ „Miejscem jest porządek (jakikolwiek) decydujący o rozmieszczeniu elementów w stosunkach wspólistnienia. W ten sposób zostaje więc wykluczona możliwość, że dwie rzeczy znajdą się w tym samym miejscu. (...) Miejsce jest więc tymczasową konfiguracją położeń. Implikuje wskazywanie stabilności” (de Certeau 2008, s. 116-117).

${ }^{22}$ Lee, Ingold 2006, s. 80.
} 
i organizują miejsca»”23. Margarethe Kusenbach ${ }^{24}$ wyróżnia pięć obszarów, w badaniu których, jej zdaniem, spacer (go-along) może być skuteczniejszą metodą, niż wspomniany wywiad czy obserwacja uczestnicząca:

- percepcję (spacer pozwala uchwycić wiedzę praktyczną, a także gust czy wartości),

- praktyki przestrzenne (i nadawane im znaczenia),

- biografie (poprzez wywoływanie wspomnień) oraz

- architekturę społeczną oraz sferę społeczną (pozwalają odnotować relacje i wzory interakcji, szczególnie w niewielkiej przestrzeni zaliczanej np. do okolicy domu).

W odróżnieniu od wywiadu spacery angażują ciało badacza, co pozwala wielozmysłowo doświadczać przestrzeni. „Ucieleśnione doświadczenie badacza stanowi wnikliwą podstawę empatycznego rozumienia bycia w przestrzeni, którego doznaje na co dzień badany” ${ }^{26}$. Umożliwia to podjęcie próby „rozumienia «w działaniu»”, co pozwala uchronić się przed narzucającym się, gotowym językiem, domkniętymi interpretacjami, które mogą wpływać na to, jak postrzegamy badaną rzeczywistość ${ }^{27}$.

\section{Zamieszkiwanie stolicy - proces wytwarzania się relacji z miastem}

Zamieszkiwanie stolicy rozpoczyna się od decyzji o przeprowadzce na studia do tego miasta. Niektórzy podejmują ją bardziej spontanicznie (np. na podstawie pojedynczej wycieczki, widoku bramy uniwersytetu), inni w sposób bardziej przemyślany (rozpatrując wszelkie za i przeciw, np. pozycję uczelni w rankingu czy odległość od miasta rodzinnego). Przy wyborze Warszawy często kluczowy był jej ogólny obraz jako miejsca - miasta, które koncentruje w sobie to, co w kraju najciekawsze (np. wydarzenia kulturalne) i najważniejsze (np. życie polityczne, finanse), jego nowoczesność, zamożność i otwartość. Ponadto daje różne możliwości, wśród których wymieniano opcje

${ }^{23}$ Bendiner-Viani 2011, s. 136. Por. także de Cerateu 2008.

${ }^{24}$ Kusenbach 2003.

${ }^{25}$ Wiedza praktyczna może być rozumiana jako umiejętność radzenia sobie „"praktyczna inteligencja», czy też «przemyślność», to forma wiedzy, którą trudno nabyć inaczej, niż poprzez uczestnictwo i która właściwie nie poddaje się uogólnieniu. Ma ona w znacznym stopniu charakter pozajęzykowy, oparty na doświadczeniu i praktyce, która zmusza do konfrontacji z kolejnymi, podobnymi do siebie, lecz nigdy nie identycznymi sytuacjami wymagającymi szybkiego przystosowania” (Klekot 2015). Jest to także wiedza umiejscowiona "usytuowana nie w samym ciele, lecz w relacji do tego ciała ze światem tu i teraz" (Klekot 2018, s. 85).

${ }^{26}$ Nóżka, Martini 2015, s. 35. To rozumienie możliwe jest, przy całym ograniczeniu fizjonomii ludzkiego ciała i sposobów używania go, dzięki wspólnej, biologicznej naturze ludzkiej (Tilley 1994, za: Smyrski 2017, s. 135).

${ }^{27}$ Rakowski 2018, s. 21. Convery, Corasne, Davis wskazują nawet, że ustrukturyzowane wywiady, kwestionariusze mogą być kontrproduktywne, jeśli chodzi o uwzględnienie nie posiadającego odbicia w słowach rozumienia miejsca i przywiązania do niego $(2012$, s. 4). 
spędzenia wolnego czasu, nauki, poznawania nowych ludzi czy znalezienia pracy. Tego typu obrazy (wyobrażenia, przekonania) odgrywają kluczową rolę w ruchu migracyjnym i są konieczne, by podjąć decyzję o migracji, a także ją zrealizować ${ }^{28}$.

Jednak zetknięcie się z rzeczywistością to moment weryfikacji oczekiwań i odkrycia, że nie wszystko w wybranym miejscu jest takie, jak by się chciało. Strategie radzenia sobie z realiami były różne. Niektórzy z moich rozmówców, choć dostrzegali braki czy minusy stolicy i nie wszystkie ich oczekiwania zostały spełnione (nie tak łatwo skorzystać z różnorodnych opcji rozwoju osobistego, ludzie okazali się nie tak otwarci na innych, nie tak łatwo znaleźć pracę), to jednak dostrzegali także plusy, które przeważały, sprawiając, że osoby te miały poczucie dokonania dobrego wyboru. Inni narzekali, z czasem dostrzegając coraz więcej minusów (korki, tłok, wysokie ceny), zmieniając zdanie co do różnych elementów, które początkowo wydawały się atrakcyjne (np. prędkość życia z żywego i energetycznego miasta Warszawa stawała się areną wyścigu szczurów). Te osoby były przede wszystkim rozczarowane i miały większą motywację do wyjazdu/powrotu do innych/rodzinnych miejscowości. Kolejni niechętnie mówili o minusach stolicy i niespełnionych oczekiwaniach. Dostrzegalna była tu niechęć do krytykowania Warszawy jako cechy typowej dla „słoika”. Niektórzy z moich rozmówców odżegnywali się od przeżywania zmiany, jaką jest przeprowadzka, sprawiając wrażenie, że takie zachowanie mogłoby uchodzić za „małomiasteczkowe”. Osoby te wyrażały się o swoim wyborze i związanej z nim zmianie w sposób zdystansowany i pragmatyczny, wskazując na potrzeby usamodzielnienia się, ukończenia dobrych studiów, nawiązania ciekawych i przydatnych relacji. Postrzeganie wyjazdu do Warszawy jako, w pewnym sensie, awansu czy też sukcesu (lub jego szansy) było ujmowane negatywnie. Podkreślano, że liczy się dobra uczelnia lub praca nad sobą, a miejsce przeprowadzki nie jest istotne (równie dobrze mogłoby paść na inne duże polskie miasto). Stosunek do stolicy był u tych osób formą kontestacji istniejącej w pewnym momencie „mody” na Warszawę jako kierunek migracji. Coraz częściej młodzi ludzie odżegnują się od obrazu stolicy jako wielkomiejskiego eldorado. Pozostaje on jednak aktualny wśród pokolenia ich rodziców lub dziadków.

W opisanych postawach widać, że stosunek do Warszawy kształtował się w odniesieniu do dwóch stereotypów. Jednym z nich było wyobrażenie stolicy funkcjonujące potocznie w miejscowościach, z których pochodzą moi rozmówcy - wyrażany przez nich samych lub starsze pokolenia, zderzający się z ich faktycznymi doświadczeniami oraz drugim stereotypem: przyjezdnego - „słoika”. Stosunek ten miał wpływ na samopoczucie, ocenę własnego przywiązania do stolicy, chęć pozostania w niej, ale także na stosunek do domu rodzinnego czy rodzinnej miejscowości.

Kolejną ważną kwestią jest sytuacja mieszkaniowa. Poszukiwanie mieszkania lub pokoju wpływało zarówno na ocenę własnej sytuacji, jak i obrazowało poziom znajomości miasta. Szczególnie w początkowym okresie, ale także później, pozwalało poznać

${ }^{28}$ Glick Schiller, Salazar 2013, s. 195. 
kolejne jego części i wyrobić sobie opinię o nich. Bo też pierwsze wynajęte mieszkanie rzadko było ostatnim. Tuż po uzyskaniu decyzji o dostaniu się na studia, jeśli tylko było to możliwe, moi rozmówcy znajdowali wśród najbliższych osób innych migrantów wybierających się do Warszawy i poszukiwali razem mieszkania (jeśli przyjaciele wyjeżdżali do innego miasta lub pozostawali w rodzinnej miejscowości, szukano dalszych koleżanek czy kolegów, których kojarzyło się i znało, np. ze szkoły). Poszukiwania w internecie (lub w przypadku starszych rozmówców, także w gazetach) kończono na wybraniu kilku ofert i umówieniu się z właścicielami mieszkań na oględziny na ten sam dzień, weekend (jeśli mieli gdzie przenocować) lub - jeśli nie było takiej możliwości - na kolejne dni, podczas których rozmówcy dojeżdżali razem do stolicy, by oglądać mieszkania i wracać w kilka godzin później.

Główne kryteria, jakimi się kierowano to cena, jaką trzeba zapłacić za miesięczne użytkowanie, jakość (wyposażenie, wykończenie) i odległość od uczelni (i co za tym idzie - komfort dojazdu). Kryteria te, choć logiczne, były trudne do oceny w sytuacji faktycznego zestawienia ofert. Duży rynek najmu w Warszawie, powoduje, że w praktyce trudno porównać ze sobą oferty i ocenić je pod kątem wspomnianych wymogów. Osoba niedoświadczona może mieć zatem problem z określeniem tego, co to znaczy dobry stosunek jakości do ceny lub ceny do położenia mieszkania w nieznanym sobie mieście. Ile to, w warunkach codziennego życia stolicy, (zbyt) duża (w minutach lub kilometrach) odległość mieszkania od centrum? By wiedzieć takie rzeczy potrzebne jest zanurzenie w kontekst danego miasta i doświadczenie różnego rodzaju odległości w życiu codziennym. Zatem, jeśli tylko istniała taka możliwość, radzono się rodziny lub znajomych, którzy mieszkali już jakiś czas w Warszawie i proszono o porady dotyczące tego, jakich dzielnic unikać, gdzie jest tanio, a gdzie drogo, ale ładnie. Kluczowe przy tym było, by ostatecznie wybrana lokalizacja umożliwiała nieskomplikowany dojazd na uczelnie wszystkim współlokatorom, nawet jeśli działo się to kosztem komfortu samego mieszkania.

$\mathrm{Na}$ późniejszym etapie, gdy rozmówcy znali już lepiej miasto (m.in. rozkład ulic, charakter poszczególnych dzielnic, specyfikę komunikacji miejskiej), a także mieli okazję porównać swoje wybory z wyborami innych znajomych, często szukali nowych mieszkań. Wiązało się to z ukształtowaniem się przekonania o tym, co dla danej osoby znaczy „dobrze” mieszkać. Nadal, najczęściej ze względów finansowych, starano się szukać mieszkania z kimś bliskim i unikano wynajmowania pokoju w mieszkaniu pełnym obcych osób. Brak takiej możliwości skazywał na losowość w doborze współmieszkańców i nie gwarantował żadnej pewności co do komfortu zamieszkiwania. Ci z moich rozmówców, którym nie udało się tego uniknąć w pewnym momencie życia, źle wspominają ten okres.

Widać tu jak ważne mogą być relacje międzyludzkie i jaki mają wpływ na poczucie danego miejsca (miasta lub jego części) i ocenę własnej sytuacji. Początkowo moi rozmówcy trzymali się znajomych z rodzinnych okolic i spędzali czas przede wszystkim 
z nimi. Mogły to być osoby, które mieszkały w tym samym miejscu (np. na tej samej ulicy), chodziły do tej samej klasy lub szkoły albo znane były np. jeszcze z wczesnego dzieciństwa. $Z$ czasem krąg ten rozszerzał się i wchodziły do niego nowe osoby, coraz luźniej związane z początkową grupą znajomych. Przewagę zyskiwały kontakty związane z uczelnią - w ramach grupy ćwiczeniowej, tego samego kierunku czy koła naukowego, a także stopniowe rozszerzanie się sieci znajomych na kręgi pozauczelniane. Współlokatorka, którą moja rozmówczyni znała jeszcze z dzieciństwa, zaprosiła na imprezę do ich domu znajomych ze swojej uczelni. W ten sposób moja rozmówczyni poznała swojego chłopaka, mieszkającego od urodzenia w Warszawie, a przez niego także jego znajomych, z którymi związała się na zasadzie więzi opartych o inne niż uczelniane kontakty. Druga z rozmówczyń dołączyła do organizacji studenckiej, gdzie nawiązała znajomość z grupą osób, która utrzymała się także po tym, gdy wszyscy zakończyli naukę. Magdalena Łukasiuk, badająca osoby, które przyjechały do stolicy w poszukiwaniu pracy, w pierwszej ze wspomnianych dyskusji o przyjezdnych pisze, że badani często pozostają w kręgu innych migrantów, rzadko nawiązując bliższe znajomości z warszawiakami, zwykle ze względu na wspólnotę doświadczeń, która łączy ich z innymi nie-warszawiakami ${ }^{29}$. $\mathrm{Z}$ moich badań trudno jednak wyciągnąc taki wniosek. Badane przeze mnie osoby wchodziły w kontakty $z$ innymi bez względu na to, czy osoba pochodziła z Warszawy czy z poza niej, dominowały tu kwestie przypadku. Faktem jest jednak, że pochodzenie $z$ tej samej miejscowości lub regionu stanowiło silną podstawę do nawiązania relacji z drugą osobą (przynajmniej na początkowym etapie tworzyło to pewną płaszczyznę porozumienia) oraz że wśród warszawskich studentów wielu pochodzi spoza stolicy, co zwiększa prawdopodobieństwo poznania kogoś z innej części Polski.

Zamieszkiwanie stolicy to także kwestie topografii i poruszania się nie tylko pomiędzy konkretnymi punktami, ale również w kontekście odnajdywania się (orientacji). Początkowo większość moich rozmówców trzymała się dość sztywnych tras uczelnia dom i nie wypuszczała się dużo dalej bez konkretnych wskazówek ${ }^{30}$. Niektórzy nosili ze sobą mapy lub korzystali z map w telefonie. Wśród najmłodszych rozmówców od początku ich przyjazdu do Warszawy popularna była aplikacja jakdojade.pl, która pozwala wyszukać połączenia komunikacji miejskiej pomiędzy punktem startowym i docelowym. Znacznie zmniejsza to ryzyko zagubienia się i obawę przed tym.

Początkowa sztywność tras szybko znika. Rozmówcy próbowali nowych sposobów dostania się w różne miejsca, gdy opanowali te pierwsze lub dowiadywali się o nich

${ }^{29}$ Eukasiuk 2007, s. 362.

${ }^{30}$ Yi-Fu Tuan przywołuje eksperyment, w trakcie którego badani przechodzili wielokrotnie ten sam labirynt, mając zasłonięte oczy. Nieznana trasa, wielokrotnie przechodzona, pokazała, że sztywność ruchów ogranicza pomyłki (choć one same są poddawane refleksji i służą nauce), a poszczególne „znaki szczególne", pojawiające się na trasie labiryntu, ulegały integracji w jedną przestrzeń w momencie odnalezienia wyjścia. Yi-Fu Tuan konstatuje, że być może ważniejsza jest znajomość sekwencji ruchów - wiedza wynikająca z ciała, a nie mentalna mapa (Tuan 2001, s. 71-72). 
przypadkiem (w związku z pomyleniem trasy albo świadomym wyborem nieznanej drogi w ramach eksperymentu). Wiedzę tę dzielili z innymi migrantami (konsultowali się ze znajomymi, współlokatorami albo sami udzielali porad), co pozwalało im na poszerzenie mentalnej mapy stolicy, dzięki czemu z czasem przestrzeń robiła się czytelniejsza ${ }^{31}$.

Konieczność załatwienia pewnych spraw, realizacji własnych potrzeb, zmuszała do coraz większego eksplorowania stolicy. Jednocześnie każda podróż to praktykowanie przestrzeni miejskiej Warszawy - sposobu i zasad funkcjonowania komunikacji miejskiej, konwenansu' ${ }^{32}$, odczytywania znaków i informacji (tych oficjalnych - systemowych, jak i mniej oficjalnych, wynikających $\mathrm{z}$ wyczucia sytuacji), poruszania się w określonych warunkach i dostosowania do niego rytmu swojego ciała (np. w określonych miejscach w stolicy chodzi się szybciej niż w innych; w metrze warto zostawić lewą stronę ruchomych schodów wolną), wytwarzania wiedzy praktycznej dotyczącej topografii miasta, a także ułożenia poszczególnych jego elementów względem siebie, powielania istniejących już wśród mieszkańców opinii lub wytwarzanie nowych, przyswajania wiedzy potocznej, zakotwiczania elementów swojej biografii w przestrzeni (wytwarzanie wspomnień i przywoływanie ich z pamięci). Taka praktyka pozwalała na coraz swobodniejsze (a więc wymagające mniej świadomej uwagi) poruszanie się po mieście ${ }^{33}$ i funkcjonowanie w nim. Umiejętność odczytania pojawiających się w przestrzeni informacji (np. takich jak hasłowo określony kierunek jazdy danego autobusu wyświetlający się tuż obok jego numeru, kojarzenie numeru danego pojazdu komunikacji miejskiej z konkretną trasą lub miejscem, przez które przejeżdża, rozpoznawanie nazwy ulicy) zapobiega zagubieniu i wzmacnia umiejętność dostosowania swojego zachowania do warunków, jakie napotyka się w przestrzeni (jeśli w danej restauracji, barze czy kawiarni nie ma miejsca, to zna się lub kojarzy w okolicy inne miejsca, w których można spędzić czas) ${ }^{34}$.

Interakcja z miejską przestrzenią to nie tylko poruszanie się czy odnajdywanie drogi, ale także przebywanie w różnych miejscach w ramach swoich obowiązków, z przypadku lub dla przyjemności. Korzystanie z konkretnych miejsc naznacza je obecnością danej osoby i osadza w nich jej wspomnienia ${ }^{35}$. W trakcie rozmów prosiłam o opowiedzenie

${ }^{31}$ Czytelność „(...) oznacza dla nas łatwość, z jaką jego [miasta - K.Z.] fragmenty mogą być rozpoznane i zorganizowane w spójny wzór." (Lynch 2011, s. 3).

${ }^{32}$ Czyli wiedzy o tym, jak zachować się w poszczególnych sytuacjach społecznych, by uniknąć konfliktu lub niezręczności (de Certeau, Girad, Mayol 2011, s. 13). Jeden z moich rozmówców opowiadał, że w początkowym okresie często spędzał czas z mieszkającym od urodzenia w stolicy kuzynem, który nieustannie wprawiał go w zakłopotanie, gdy wytykał mu „potknięcia” - nie powinno się np. dotykać obcych osób (mój rozmówca zdjął nieznanej kobiecie pająka z ramienia).

33 „Poznanie miejsca (...) w sposób oczywisty wymaga czasu. Jest to znajomość podświadoma. Z czasem miejsce staje się coraz bardziej swojskie, co oznacza, że coraz więcej jego elementów bierzemy za pewnik. $\mathrm{Z}$ czasem nowy dom przestaje wymagać od nas uwagi, staje się komfortowy, nie rzuca się w oczy (...)” (Tuan 2001, s. 184. Tłumaczenie własne).

${ }^{34}$ Por. Lefebvre 1991, s. 47-48.

35 „Opowieści (...) każdego dnia przemierzają i organizują miejsca, wybierają je i łączą, tworzą z nich zdania i szlaki. Są przestrzennymi trasami” (de Certeau 2008, s. 115). 
o miejscach, które są ważne czy lubiane. Rozmówcy często wymieniali różnego rodzaju lokale gastronomiczne, kina, place czy parki i mówili o spędzaniu tam czasu samemu/ samej lub wraz ze znajomymi. W trakcie spaceru naznaczenie danego miejsca biografią danej osoby stawało się bardziej wyraziste, a to, co zbyt ulotne, by dać się ubrać w słowa $\mathrm{w}$ trakcie wywiadu, pojawiało się $\mathrm{w}$ momencie przechodzenia lub bycia wspólnie $\mathrm{w}$ danym miejscu. Jak bowiem piszą Marcjanna Nóżka i Natalia Martini:

Człowiek (re)produkuje miejsca tak przez swoje wspomnienia, wyobraźnię, emocje, jak i doświadczanie ich za pośrednictwem wszystkich swoich zmysłów. Tym samym to nie tylko wzrok dostarcza informacji pozwalających na konstruowanie obrazu miejsca. Na doświadczenia i kreowany wizerunek tegoż składa się także ruch (...), dźwięk (...), zapach (...), dotyk (...), smak $^{36}$.

Dzięki temu umieszczenie sytuacji badawczej w określonej przestrzeni, która pobudzała zmysły moich rozmówców, umożliwiało wydobycie wspomnień, skojarzeń i historii, które nie miały szansy zaistnieć w momencie wywiadu. W trakcie jednej z takich wycieczek wysiedliśmy wraz z moim rozmówcą na przystanku autobusowym obok akademika, w którym dawniej mieszkał. Choć bywałam w tej okolicy kilka razy, potrzebowałam chwili na zorientowanie się, na jakim przystanku jestem, gdzie znajduje się akademik i w którą stronę powinniśmy iść. Mój rozmówca natomiast w ogóle się nie zastanawiał, wysiadając $z$ autobusu skręcił od razu w prawo i podążył do przejścia dla pieszych. Ta sytuacja wywołała $\mathrm{w}$ nim określone wspomnienie powrotu $\mathrm{z}$ imprezy wraz ze znajomymi, które opowiedział mi, gdy czekaliśmy na zmianę świateł. Miało ono charakter impresji - nie było związane bezpośrednio $\mathrm{z}$ rozmową, którą prowadziliśmy, ale ewokowane przez znajomą sytuację i miejsce (opuszczanie autobusu na tym konkretnym przystanku wraz z kimś znajomym). Tego rodzaju wspomnieniowe anegdoty pojawiały się podczas wszystkich spacerów i były wywoływane tematem, którego pośrednio dotyczyły. Mówiły o błahych lub ważnych elementach biografii moich rozmówców i pojawiały się nieustannie $\mathrm{w}$ trakcie spaceru.

Gdy z moim rozmówcą przeszliśmy przez ulicę i weszliśmy na Pole Mokotowskie, znaleźliśmy się w przestrzeni, w której krzyżowały się rozmaite fragmenty życia codziennego mojego rozmówcy - zarówno bardzo osobiste (codzienne spacery przez Pole do domu swojej dziewczyny i z nią), jak i opierające się o zbiorowe praktyki (wykorzystanie Pola jako miejsca piknikowego, gdzie mimo oficjalnego zakazu można spożywać alkohol, ponieważ robi to naraz tak wielu ludzi rozproszonych po całym parku, że uczestnikom trudno wyobrazić sobie, by policja lub straż miejska mogły wystawić mandaty każdemu z nich), dotyczące teraźniejszości (chodzenie zawsze tym samym skrótem przez zarośla), jak i przeszłości (spotkania z przyjaciółmi w nieistniejącym już pubie na tym terenie).

${ }^{36}$ Nóżka, Martini 2015, s. 37. 
Inny z moich rozmówców wskazywał Krakowskie Przedmieście jako jedno z ważnych dla niego miejsc. Ulica ta służy na co dzień zarówno turystom zwiedzającym Stare Miasto, sprzedawcom kwiatów i pączków, jak i studentom przemieszczającym się na zajęcia z jednej lokalizacji do drugiej. Dla tego rozmówcy Krakowskie Przedmieście związane jest ze wspomnieniem okresu studiów, o czym opowiadał, uwzględniając zarówno elementy dźwiękowe otoczenia, jak i pogodę, która miała wpływ na percypowanie przestrzeni:

Najbardziej chyba cieszyło swego czasu na pierwszym roku, kiedy przyjeżdżałem w soboty rano na dziewiątą na wykład $\mathrm{z}$ historii filozofii starożytnej u profesora B., prowadzony dla studentów zaocznych. Wtedy było pusto, ruch [autobusowy] w weekendy już wiosną chyba był wstrzymany. Było też ciepło, słonecznie i Krakowskie Przedmieście prezentowało się zupełnie inaczej ${ }^{37}$.

Choć niepozorne, tego typu historie wypełniają przestrzeń Warszawy i wyłaniają się, gdy ich właściciele przemierzają konkretne jej części, świadcząc o swoim życiu i bardzo praktycznym, bo cielesnym, zmysłowym, zanurzeniu w nurt jej życia, a także o powiązaniu własnej biografii z topografią. Jak pisze Yi-Fu Tuan „czucie” miejsca („feel” of place) „wyłania się z doświadczeń, zwykle przelotnych i pozbawionych dramatyzmu, powtarzanych dzień po dniu i przez lata. Jest niepowtarzalną mieszanką widoków, dźwięków i zapachów, unikalną harmonią naturalnych i sztucznych rytmów, takich jak pora wschodu i zachodu czy pracy i zabawy. Czucie miejsca zarejestrowane jest w mięśniach i kościach"38.

\section{Podsumowanie}

Omówiony materiał miał na celu przedstawienie różnych praktyk, które mogą składać się na proces zamieszkiwania i ukazanie, jak wyłania się w jego trakcie pewna zręczność, która pozwala moim rozmówcom na realizowanie swojego codziennego życia w sposób płynny i stabilny. Jednocześnie należy zauważyć, że osiągnięcie tego rodzaju umiejętności niekoniecznie wiąże się z pozytywnie rozumianym przywiązaniem do miejsca i identyfikacją z nim. Wśród rozmówców dominowały trzy główne tendencje. Pierwszą z nich była deklaracja chęci pozostania w stolicy i identyfikacja $\mathrm{z}$ nim. Takie osoby, choć miały świadomość napięć, jakie występują ze strony „prawdziwych” warszawiaków i nie odżegnywały się od pochodzenia $z$ innych miejsc Polski, postrzegały Warszawę jako „swoje” miejsce. Ten proces można by nazwać adaptacją, która wiąże się $\mathrm{z}$ mentalną akceptacją stolicy jako miejsca, gdzie jest dom ${ }^{39}$. Drugą z nich była deklaracja

\footnotetext{
${ }^{37}$ Materiał zebrany w trakcie badań do pracy magisterskiej, rozmowa z Jankiem pochodzącym z Kielc.

${ }^{38}$ Tuan 2001, s. 183. Tłumaczenie własne.

${ }^{39}$ Eukasiuk 2007, s. 217.
} 
chęci pozostania w stolicy przynajmniej na jakiś czas lub otwarte mówienie o byciu tu na czas studiów, a potem, być może, przeprowadzce (w zależności od tego, co przyniosą kolejne lata). Ten rodzaj wypowiedzi cechował osoby, które nie chciały jasno się określać i pozostawiały sobie czas na decyzję. Tego typy postawę, za Magdaleną Łukasiuk, można nazwać instalacją - tj. oswojeniem się z danym miastem, ale bez wspomnianej wyżej akceptacji. Dla takich osób wyjazd do Warszawy może być rodzajem treningu, przygotowującego je do kolejnej przeprowadzki po studiach ${ }^{40}$. Trzecia grupa to najstarsi z moich rozmówców, którzy skończyli już studia. Niektórzy znaleźli już pracę, wciąż jednak zastanawiali się, czy zostać czy też wyjechać. Nie mogąc podjąć decyzji, chcąc nie chcąc, osiadali coraz mocniej w Warszawie, jednocześnie marząc o zmianie. Tego rodzaju postawa przypomina dryfowanie (floating), które opisuje niezdolność do zdecydowania o powrocie lub pozostaniu, brak poczucia zakorzenienia, stabilności, niepewność i tymczasowość. Wśród tych osób dominuje melancholia związana z odczuwanym brakiem sprawczości ${ }^{41}$.

Tendencje te nie wyczerpują możliwych relacji z miastem, a sposoby jej wytwarzania zapewne są znacznie bardziej skomplikowane, niż zostało to ujęte w artykule. Stanowi on jednak próbę przełożenia teorii dotyczących zamieszkiwania na inny niż zwykle teren - miejski i dotyczący „rodzimego” Innego.

\section{Bibliografia}

Bendiner-Viani G. 2011, Spacerowanie, emocje i zamieszkiwanie. Wycieczki z przewodnikiem po Prospect Heights w Brooklynie, [w:] Frąckowiak M., Olechnicki K., Krajewski M. (red.), Badania wizualne w dziataniu. Antologia tekstów, Fundacja Nowej Kultury Bęc Zmiana, Warszawa, s. 135-154.

Chełmiński J. 2017, Mieszkańcy polskich miast: Warszawa, „Gazeta Wyborcza”, http://biqdata. wyborcza.pl/biqdata/7,159116,22175044,mieszkancy-polskich-miast-warszawa.html, 01.11.2018.

Coates J. 2013, Everyday Mobility: The Normalization of China-Japan Migratory Flows and They 'Everyday Practice', "International Review of Social Research", Vol. 3., no. 1, s. 7-26, https:// www.researchgate.net/publication/276431737_Everyday_Mobility_the_Normalization_ of_China-Japan_Migratory_Flows_and_their_'Everyday_Practice', 17.01.2019.

Convery I., Corasne G., Davis P. (red.) 2012, Making Sense of Place. Multidisciplinary Perspectives, The Boydell Press, Woodbridge.

De Certeau M. 2008, Wynaleźć codzienność. Sztuki dziatania, Wydawnictwo Uniwersytetu Jagiellońskiego, Kraków.

${ }^{40}$ Eukasiuk 2007, s. 253.

${ }^{41}$ Coates 2013. 
De Certeau M., Giard L., Mayol P.2011, Wynaleźćcodziennośc. 2. Mieszkać, gotować,Wydawnictwo Uniwerystetu Jagiellońskiego, Kraków.

Faist T. 2013, The mobility turn: a New paradigm for the social sciences?, „Ethnic and Racial Studies”, Vol. 36, No. 11, s. 1637-1646.

Glick Schiller N., Salazar N. B. 2013, Regimes of Mobility Across the Globe, „Journal of Ethnic and

Migration Studies", Vol. 39, No. 2, s. 182-200, https://www.researchgate.net/publication/256049169_Regimes_of_Mobility_Across_the_Globe, 17.01.2019

Grzelak J., Zarycki T. (red.) 2004, Spoteczna mapa Warszawy. Interdyscyplinarne studium metropolii warszawskiej, Wydawnictwo Naukowe SCHOLAR, Warszawa.

Gustafson P. 2001, Roots and Routes: Exploring the Relationship between Place Attachment and Mobility, „Environment and Behaviour”, Vol. 33, s. 667-686.

Heidegger M. 2007, Budować, mieszkać, myśleć, [w:] Heidegger M., Odczyty i rozprawy, Altheia, Warszawa, s. 139-157.

Highmore B. 2002, Everyday Life and Cultural Theory, Routledge, Londyn, Nowy Jork, http:// www.academia.edu/5722594/Everyday_life_and_cultural_theory, 01.11.2018.

Ingold T. 1993, The temporality of the landscape, „World Archeology”, Vol. 25, No. 2, s. 152-174.

Ingold T. 2000, The Perception of Environment. Essays on Livelihood, Dwelling and Skill, Routledge, Londyn, Nowy Jork.

Ingold T. 2011, Being Alive. Essays on Movement, Knowledge and Description, Routledge, Londyn, Nowy Jork.

Klekot E. 2015, Obcowanie z materią: mētis jako rodzaj wiedzy, „Autoportret”, nr 1[48], http:// autoportret.pl/artykuly/obcowanie-z-materia-metis-jako-rodzaj-wiedzy/, 13.01.2019.

Klekot E. 2018, Mètis - wiedza asystemowa, „Teksty drugie”, nr 1, s. 79-90.

Kusenbach M.2003, Streetphenomenology. The go-along as ethnographic research tool, Ethnography”, Vol. 4, No. 3, s. 455-485, https://www.jstor.org/stable/24047846, 13.01.2019.

Lee J., Ingold T. 2006, Fieldwork on Foot: Perceiving, Routing, Socilizing, [w:] Coleman S., Collins P. (red.), Locating the Field. Space, Place and Context In Anthropology, Bloombury Publishing, Londyn, Oksford, Nowy Jork, New Dehli, Syndey, s. 67-86.

Kwaśniewski T. 2004, Rozmowa o badaniach: jacy warszawiacy - jaka Warszawa, „Gazeta Wyborcza”, http://warszawa.wyborcza.pl/warszawa/1,54420,2283622.html, 01.11.2018.

Lefebvre H. 1991, The Production of Space, Blackwell, Cambridge.

Lynch K. 2011, Obraz miasta, Wydawnictwo Archivolta Michał Stępień, Kraków.

Łukasiuk M.2007, Obcy w mieście. Migracja do wspótczesnej Warszawy, Wydawnictwo Akademickie „Żak”, Warszawa.

Nóżka M., Martini N. 2015, Metody mobilne i wizualne w praktyce badawczej. Zastosowanie fotospaceru w socjologicznych badaniach map mentalnych u zachowań terytorialnych ludzi, „Przegląd Socjologii Jakościowej”, Tom XI, nr 4, s. 35-50, http://www.qualitativesociologyreview. org/PL/Volume32/PSJ_11_4_Nozka_Martini.pdf, 15.01.2019.

Rakowski T. 2018, Etnografia przedtekstowa. Fenomenologiczne korzenie interpretacji antropologicz$n e j$, ,Teksty drugie”, nr 1, s. 16-39. 
Seamon D. 2014, Place Attachment and Phenomenology: The Synergistic Dynamism of Place, [w:] Manzo L.C, Devine-Wright P. (red.), Place Attachment. Advances in Theory, Methods and Applications, Routledge, Londyn, Nowy Jork, s. 11-22, http://www.academia.edu/4321988/ Place_Attachment_and_Phenomenology_The_Synergistic_Dynamism_of_Place_2014_, 01.11.2018.

Skowrońska M. 2015, Jak u siebie. Zamieszkiwanie i komfort, Zakład Wydawniczy „Nomos”, Kraków.

Smyrski Ł. 2017, Antropologia krajobrazu - na pograniczu dyscyplin, „Etnografia Polska”, tom LXI, zeszyt 1-2, s. 125-146, http://rcin.org.pl/Content/65946/WA308_85283_P326_Antropo logia-krajobr_I.pdf, 17.01.2019.

Tuan Y. 2001, Space and Place. The Perspective of Experience, University of Minnesota Press, Minneapolis.

Woroniecka G. (red.) 2007, Co znaczy mieszkać. Szkice antropologiczne, Trio, Warszawa.

\section{Źródła internetowe}

Sprzeciw wobec realizacji zwycięskiego projektu - NEON DLA WARSZAWY, https://www. facebook.com/events/464243060320038/?ref=22, 19.06.2019. 